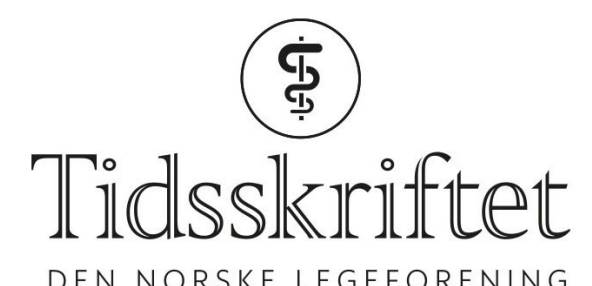

DEN NORSKE LEGEFORENING

\title{
K.L. Iversen og medarbeidere svarer
}

KOMMENTAR

\section{KAJA LUND IVERSEN}

E-post: Kaja.Lund-Iversen@forbrukerradet.no

Kaja Lund Iversen er seniorrådgiver i Forbrukerrådet.

Ingen oppgitte interessekonflikter.

\section{ERIK ARNESEN}

Erik Arnesen er helsefaglig rådgiver i Landsforeningen for hjerte- og lungesyke. Ingen oppgitte interessekonflikter.

\section{HELLE MARGRETE MELTZER}

Helle Margrete Meltzer er forskningssjef i Folkehelseinstituttet. Ingen oppgitte interessekonflikter.

\section{ANNE LISE BRANTSAETER}

Anne Lise Brantsæter er seniorforsker i Folkehelseinstituttet. Ingen oppgitte interessekonflikter.

Barnelegeforeningen erkjenner at det økende forbruket av høykoffeinholdige energidrikker hos barn og unge er et problem, og er enige i at tilfeller av alvorlige akutte forgiftninger gir stor grunn til bekymring. Den vil likevel vente på en risikovurdering fra Vitenskapskomiteen for mat og miljø før den tar stilling til om forbud mot salg av energidrikker til mindreårige er riktig tiltak.

Barn og unge er i en svært sårbar fase av livet, både fysisk, mentalt og sosialt. Statistikken viser tydelig at dagens regulering i Norge ikke hindrer barn og unge i å bruke energidrikker. Både advarselsmerking og den tilfeldige selvreguleringen som skjer i dagligvarebutikkene, er ineffektive virkemidler. Myndighetene har et ansvar for å beskytte sårbare grupper og legge til rette for at barn og unge tar gode valg.

Ingen er uenig i at det trengs mer kunnskap om skadeeffektene av energidrikker, men vi er forpliktet til å handle ut fra den kunnskapen vi har. Dette fastslår også presidenten for The Royal College of Paediatrics and Children's Health i en kommentar i tidsskriftet BMJ nylig (1), der han gir uforbeholden støtte til myndighetenes forslag om å innføre aldersgrense for kjøp av energidrikker i Storbritannia (2). Barnelegeforeninger i en rekke andre land har uttalt at barn og unge ikke bør bruke energidrikker. I Nederland har barnelegeforeningen fremmet forslag om innføring av 18-årsgrense (3). Vi håper den norske barnelegeforeningen vil følge etter og støtte dette som et nødvendig tiltak. 
1. Viner R. Ban on sale of energy drinks to children. BM] 2018; 362: k3856. [PubMed][CrossRef]

2. UK Government. Public asked for views on banning energy drink sales to children.

https://www.gov.uk/government/news/public-asked-for-views-on-banning-energy-drink-sales-to-child ren (27.9.2018).

3. Nederlandse Vereniging voor Kindergeneeskunde. Factsheet energiedranken. 2017.

https://www.nvk.nl/Portals/o/Kwaliteit/Factsheet\%2oenergiedranken.pdf (27.9.2018).

Publisert:30. oktober 2018. Tidsskr Nor Legeforen. DOI: 10.4045/tidsskr.18.0774

(C) Tidsskrift for Den norske legeforening 2020. Lastet ned fra tidsskriftet.no 